\title{
THE IDEA OF BEING IS Not UNIQUELY INNATE
}

\author{
INGE-BERT TÄLJEDAL
}

\begin{abstract}
According to the Italian philosopher Antonio Rosmini (1797-1855), being is an innate idea that is requisite for contemplating anything. He emphatically claims that it is the one and only innate idea. Rosmini makes a sharp distinction between sensations and perceptions. Perceptions are thought to arise when the undetermined idea of being (tantamount to possibility) is combined with sensations, universals when being is combined with perceptions. It is argued here that Rosmini's explanation of the origin of universals does not work. If the idea of being is regarded as innate, then several others should be similarly regarded, notably the idea of qualitative identity which is an idea necessary for deriving universals. Although Rosmini holds that certain properties are necessarily present in real objects and therefore implicit in the idea of being, the property of being qualitatively identical with something else is not among those properties. Theological motives may have encouraged Rosmini to emphasize being as a peculiarly fundamental idea. However, if the idea of being is more fundamental than other universals, it may be regarded so in virtue of its generality, not because it has a uniquely innate character.
\end{abstract}

Keywords: Rosmini; innate ideas; the idea of being; identity; universals.

\section{Introduction}

The Italian philosopher Antonio Rosmini (1797-1855) claimed that humans are endowed with one, and only one, innate idea. This unique idea is that of being or, in Rosmini's original Italian, essere or ente. In the general sense of existing, whether mentally or physically, being is pivotal in Rosmini's philosophical system. He considers it an intuition that is logically requisite for contemplating the existence of anything and, indeed, for mentality in general (Rosmini 1875, I: p.421, section 384): ${ }^{1}$

... if the idea of being is removed, human knowledge and the mind itself are rendered impossible.

The intuitive idea of being is not a judgment but a condition for judging the existence of anything, whether by rational deliberation or on the basis of sensations. This idea combines with sensations to form the perceptions of things. It is not itself obtainable by deliberation or by abstraction from sensations. As it is neither rationally nor empirically acquired, allegedly it must be innate.

All other ideas ultimately derive from experience. However, as emphatically argued (Rosmini 1875-76), Rosmini's epistemology differs from the empiricisms of Locke, Hume, Condillac, Reid and others regarding the connection between sensory

Principia 20(0): 343-359 (2016).

Published by NEL — Epistemology and Logic Research Group, Federal University of Santa Catarina (UFSC), Brazil. 
events and the cognitive perceptions. According to Rosmini's distinctive claim, mere sensations cannot by themselves give rise to ideas, including that of existence, an ineptitude allegedly overlooked by others. ${ }^{2}$

The purpose of this paper is to challenge Rosmini's contention that being is the one and only innate idea. I shall do so without entering into the question of whether innatism is at all a reasonable hypothesis. ${ }^{3}$ For the sake of argument, I shall assume that the concept of innate idea is consistent. I shall take it for granted that an idea is innate if it is not acquired by rational deliberation, not based on empirical perception, and not caused by some kind of exogenous mental manipulation such as hypnosis or supernatural revelation.

\section{Material}

My criticism is directed against the position taken by Rosmini in his three-volume work Nuovo Saggio sull'Origine delle Idee (Rosmini 1875-76); a translated version is available as A New Essay Concerning the Origin of Ideas (Rosmini 2001). ${ }^{4}$ Quotations, referred to by volume, page and section number, are from the 1875-76 Intra edition read on the internet sites www.archive.org or www.openlibrary.org. The translations from Italian into English are my responsibility. Somewhat more verbatim than those published by the Rosmini House (Rosmini 2001), they agree in essential meaning. The original Italian passages are presented in footnotes.

An ordained priest, Rosmini is known for his somewhat spectacular relations to the Vatican. A couple of his works were placed on Index Librorum Prohibitorum from 1849 to 1854 , and some of his views officially condemned in 1887 . Nonetheless, he was to be rehabilitated by the Catholic church and in 2007 was proclaimed Blessed. Much of Rosmini's writings is theological or about ecclesiastical matters. The idea of being is attributed an important role not only in knowledge acquisition but also in his religiously determined ontology and ethics (e.g. Baggio 2016). However, it should be emphasized that Rosmini's epistemology, as well as his views of language (Brugiatelli 2000a,b), can be understood and discussed from a purely profane point of view, without any necessary link to religious metaphysics.

\section{The allegedly uniquely innate idea of being}

In objection to the Kantian epistemic forms, which Rosmini considers to be too many and too determined, he writes (Rosmini 1875, I: pp.420-21, section 384): ${ }^{5}$

Let us conclude: the human mind has no innate determinate form, and Kant's seventeen forms have no true foundation and are completely superfluous in the explanation of the origin of ideas.

Principia 20(3): 343-359 (2016). 
On the contrary, the human mind has a single, indeterminate form and this is the idea of being in its universality.

The idea of being in its universality is pure form and has no material element associated with it; it is not subjective, but rather per se objective: it is so simple and elementary that it cannot be simplified further, nor can one imagine anything more elementary informing our cognitions: at the same time it is infinitely fertile.

And it is truly impossible to imagine any act whatsoever of the mind which does not need this form and is not nurtured and informed by it; therefore, if the idea of being is removed, human knowledge and the mind itself are rendered impossible.

As is obvious here, Rosmini vacillates between the terms "form" and "idea" when describing the denotation of the word "being" (essere, ente). This ambiguity reflects the fact that the Rosminian terms essere and ente do not fundamentally refer to an idea in the sense of an object of the mind, a concept, but to the form of cognition. Secondarily, being as form - i.e. in its abstract generality, tantamount to possibility — can be reflected upon as an idea proper. Rosmini views ideas as composed of a categorial or formative part, i.e. ideal being or possibility, and some experiential material that ultimately derives from empirical physical sensation; it is only the formative part that is assumed to be innate.

The ambiguity between Rosminian being as conceptual form and as a concept was thoroughly discussed by Gentile (1958, pp.170ff.) as regards the similarities and differences between Platonic innate ideas, Kantian categories, and the Rosminian essere. However, the distinction between ideal form and conceptual idea is not significant for the criticism I am going to make. Whether or not one focuses on being as a form for knowledge or as a mental object, I shall argue that it cannot be the sole innate idea. To the extent that the idea of being functions as a knowledge form, there are other innate ideas, too, with such function. To the extent that the idea of being is an innate object of thought, other innate ideas, too, are such objects.

Although according to Rosmini, the idea of being cannot be obtained by abstraction from sensations, it combines with physical sensations to form our perceptions. The mere possession of the innate idea is not knowledge, but the idea makes the mind prepared for intelligent awareness of things in the world. A priori, the experiencing subject possesses the innate idea of being in its most general sense, $i$. e. as an intuition of undetermined possibility. On the other hand, the body receives physical effects which cause sensations, regarded as modifications of a fundamental background sentiment (sentimento fondamentale; Brugiatelli 2000a). Rosmini views the experiencing subject as a unique force that combines the innate general idea of being with the sensations that arise spontaneously in the body or as a result of the body's physical interaction with its surroundings; sensations alone are not perceptions (Ros- 
mini 1875, I: pp.24-25, section 55): ${ }^{6}$

To illustrate with an example, let us assume that my senses are struck by some sensible agent, a tree, a stone, an animal etc. At first I shall have all those sensations which that sensible agent produces in my senses, of colour, of size, of shape, of movement etc. As long as I have all those sensations merely passively, as modifications of my sensitivity, without any operation of my intention, I have not yet conceived any object in an intellectual way. For me to conceive it intellectually, my spirit must make a judgment, i.e. say to itself "there exists something with sensible qualities such and such, etc." (that is to say, those qualities perceived by my senses). Making such a judgment I attribute existence to a real thing, of which I have perceived with my senses only the sensible qualities, and so perceive the very object intellectually. The universal idea, of which I make use in this judgment, is the idea of existence, and if I had not already possessed it, it would have been impossible for me to apply it to my sensations $[\ldots]$

As much as Rosmini asserts that knowledge acquisition requires an a priori idea, he rejects the Kantian view that the categories are conditions of cognition, viewing them instead as representing real qualities of objects, without which qualities the objects could not exist. The Rosminian being is taken to be the one and only a priori necessary innate form for perception and cognition (Rosmini 1875, I: pp.363-5, section 335): ${ }^{7}$

Kant gratuitously assumes that whenever we perceive an external object with our understanding, we are obliged also to perceive intellectually its quantity, its quality, and its relationship. This shows that he had not inquired deeply enough into the nature of the intellectual act with which we perceive things. In fact, to be able to perceive something real with my understanding, I have to judge that it exists; but I do not need to judge about anything else: I do not need to attribute expressively any quantity, quality, and relationship to the same thing. I can suspend judgment on all these matters and still perceive the thing intellectually: provided I say to myself: "it exists".

This judgment which I make in the first act of intellectual perception could be expressed as follows: "Something exists which modifies my senses", in which statement it is implicitly contained that the thing must certainly be endowed with all the conditions of existence. [...]

Kant's error here consists in assuming that the four categories, i.e. quantity, quality, relation, and modality, are conditions of the intellectual perception or, as he says, of the experience: whereas they are merely conditions of the existence of the external things.

Certainly, no bodily object can exist without quantity, quality and relationships: but all these things that are in it or belong to it need not be intellectually perceived by me together with it, for me to be able to say that I have perceived or conceived the object. Rather, in every object there are always many concealed properties which only time and long studies reveal. Nev-

Principia 20(3): 343-359 (2016). 
ertheless, the thing could have been perfectly well perceived without any thought of these properties or qualities.

I do not want to take issue with the combination of innate form with empirical content. That whiff of a Kantian paradigm is not my target. For the sake of the argument, I shall even concede that the logical structure of Rosmini's epistemology can account for our knowing that something exists, not as a merely imagined potentiality but as an objective reality distinct from the subject. My concern is solely with Rosmini's claim that the idea of being is the one and only innate idea. By insisting that our knowledge is not structured by any other innate ideal form, I think he goes too far in seeking an original epistemological position.

The first third of Nuovo Saggio is a historical overview, where Rosmini divides preceding seminal philosophers into two major groups: those who have assumed too many innate ideas (notably Plato and Kant), and those who have assumed none (Locke and followers). Placing himself in the middle, Rosmini considers others to be utterly mistaken, as there is precisely one innate idea. As being in its undetermined generality - i.e. possibility - applies to everything experienced or consistently thinkable, it is the most universal of all universals.

However, even if one were to admit that Rosmini's theory explains our knowing that something exists, I do not think that it can account for our experiencing the world as a manifold of separate things, or for our structuring of that manifold by means of universals and classification. Universals are necessary for both rational and empirical knowledge. Rosmini claims that they can be derived from the idea of being in conjunction with sensations (Rosmini 1875, I: p.421, section 384): ${ }^{8}$

So, having in this way reduced to the minimum possible what can be innate in the human mind, it now only remains for me to show how this minimum is nevertheless sufficient to explain fully the origin of all our ideas...

Moreover (Rosmini 1875, I: p.308, section 295): ${ }^{9}$

Indeed, the difficulty proposed by me consists in explaining how we first begin to form judgments. If there is only one innate idea, we already have enough: because by using this idea we can have at our convenience a series of judgments; and these judgments give us other ideas; and so with these we form still further judgments and further ideas. It is necessary, therefore, to examine closely the genealogy of ideas: this leads us to see that they all come from one stock only, a first idea, the essence of ideas, through which alone we come to possess in its fullness the faculty of judgment.

Thus, according to Rosmini, when our sensations are linked to the idea of being, perceptions arise. Judgments, in their turn, occur when the mind performs operations of reflexion on the perceptions (Rosmini 1876, III: p.8, section 1042): ${ }^{10}$ 
We have seen that there is in the human being: $1^{o}$ the sensation (1), ${ }^{11} 2^{o}$ the idea of being, and $3^{\circ}$ a unique force (the sensing and intelligent subject) which unites what is felt and the idea of being, and forms the intellective perception of things.

The spirit reflects on these intellective perceptions, and so doing performs various operations by which it extracts the ideas from them, and by means of these actions, unites and breaks down ideas and perceptions and continually forms judgments and reasonings.

All human knowledge originates in these few sources.

Simple sensation cannot be called knowledge: it is merely the matter of knowledge.

As for the various operations of reflection which extract ideas from the intellective perceptions, the formation of universals other than being is, of course, crucial. This is all the more so, as Rosmini recognizes that an individual object can only be placed in a certain class of objects if we know the universal concept that defines that class. He writes (Rosmini 1876, II: pp.52-3, section 448): ${ }^{12}$

[O]ne cannot classify anything unless he is supposed to possess on beforehand the general idea constituting the class: in other words, one cannot compare and know what is similar or dissimilar in two individuals without first having the abstract idea common to both of them; without this idea one would perceive the two similar individuals, e.g. two red pieces of cloth, but one would not think or reflect at all about their similarity; the two red sensations, perceived by our senses, would remain separate, at least in time and place, as long as they were simply sensations with different, incommunicable existence. [...] Therefore, the Lockian reflection on our sensations, with the intention of extracting ideas without possessing any on beforehand, is impossible; rather, it is the ideas that direct the spirit in its reflections and offer it the possibility of uniting and analysing the sensations and to move its attention freely from one to the other.

In the first volume of Nuovo Saggio Rosmini criticizes Locke for rejecting innate ideas altogether and for so failing to explain the perception of particulars. Here he wants to prove that some idea must be innate in order for us to be able to derive universals from particulars.

The focus of the argument is this: the similarity or qualitative identity of two or more things in the world cannot be judged, or even noticed, unless one already knows the universal idea that defines the similarity or identity in question. When presented with two red pieces of cloth, we cannot group them together as belonging to the class of red objects, unless we already have the universal idea of redness available as a structuring tool that allows us to pick out precisely red objects, and no others, as members of the class of red objects.

Principia 20(3): 343-359 (2016). 
At the same time, Rosmini claims that no universal is innate, except the general idea of being. Somehow, all other universals must be derived from perceptions. The pressing question is now whether this combination of tenets is logically consistent. It lies close at hand to suspect that Rosmini is subject to circular reasoning. To derive a specific universal, say redness, from perceptions, one must somehow manage to distinguish and single out perceptions of red from all other perceptions. However, that cannot be done unless one has access to the universal of redness as a tool for picking out precisely those perceptions. Generally, the universal $U$ is needed to identify $U$-ish objects as precisely $U$-ish objects. On the other, the universal $U$ is derived from the perception of $U$-ish objects. Such a circle leaves the origin of universal ideas unexplained, a fact that would nullify Rosmini's bold claim to have discovered the origin of ideas.

In fact, the problem is worse. For not only do we as yet lack a clear and consistent explanation of the origin of the specific universals that bring order to all qualities and objects in the world. At the root of the problem lies the fact that the overriding ideas of qualitative identity and similarity are left unexplained. Those ideas are also universals, although of a more general kind than, say, that of redness. The idea of identity defines the huge class of everything that is in some sense qualitatively identical to something else. It is logically prior to the formation of any other universal. ${ }^{13}$

To recognize identity or similarity, it is necessary to perform a comparison, a certain operation of the mind. That operation involves deciding which sensations, perceptions or individuals are to be compared. In other words, we need to focus our attention, at least momentarily, on certain sensations, perceptions or individuals rather than on others, with the purpose of deciding whether or not they are identical in some specific sense. That operation would be impossible if one did not already know what it means to be identical to something else. So, one must possess the idea of qualitative identity before one can judge whether, and to what extent, two sensations are identical to each other. In common language, identical is certainly not synonymous with being. What, then, is the origin of the idea of identity?

From a purely logical point of view, one could perhaps attempt three different ways of saving consistency in Rosmini's epistemology, the basic tenet of which is that there are no innate ideas except being.

Firstly, could it be that identity is somehow directly sensed, without involving intellective reflections of the mind, and so is not an idea but a sensation? Or, conversely, is it an idea that is arrived at by rational deliberation only, and not at all from sensation? Or, thirdly, could the idea of identity result from the unlimited mental replication of individual perceptions, i.e. be constructed by the mind on the basis on individual sensations?

The first option can be quickly rejected, I think. Qualitative identity is a relation between individuals, a relation that is general in the sense that it does not depend 
on any specific sensory quality. We do not have any sensory apparatus specialized for detecting qualitative sameness as such. Perhaps one could speculate that each physical sensory system has a built-in capacity for signalling the simultaneous plurality of triggering instances of a certain quality. However, it seems highly unlikely that there are primitive sensations of identity in the general, i.e. regardless of the specific quality of the relata. Identity is not a sensation.

Secondly, if the idea of identity has a purely rational origin, it must be implied by that of being, if, as claimed by Rosmini, being is the only innate idea. Such an explanation would seem entirely ad hoc. Were it not for a wish to escape from the above circularity, one would not come to think that qualitative identity is perhaps implied by being. ${ }^{14}$ But even if it were, that would not mean that that idea of identity is the same as that of being. If one cannot possess the idea of being without also possessing that of identity, our obtaining the idea of being by birth would imply that we get at least two ideas by birth, not merely one (see below, Elementary concepts of the idea of being).

The third escape route from circularity does not look any more promising. However, it seems to be the one opted for by Rosmini himself, and so should be given serious consideration. Reflecting on being and other ideas as implying possibility, he writes (Rosmini 1876, II: p.36, section 431): ${ }^{15}$

And indeed, we have shown that in the pure idea we think only possibility, indicating nothing about the subsistence of the thing [...]: furthermore, we have shown that the possibility of a thing extends to the unlimited repetition of that thing, and one cannot think that it is not so, which is to say that the characteristics of universality and necessity are contained in that of possibility $[\ldots]$.

And, indeed, it is always the idea of being, clothed with determining qualities drawn from experience, that provides me with a quantity of more or less determinate ideas or concepts, which, however, do not represent more than merely possible, not yet subsistent, entities. ${ }^{16}$

It should be noted that Rosmini takes the diversity of sensations for granted. It is not the innate idea of being or possibility that makes the world appear as a manifold in our perceptive experience. The idea of possibility clearly does not entail that the world is a manifold. Rather, the fact that many different universals are used to structure our knowledge of the world reflects the differences between our various sensations, not the innate idea of being. Various qualities are in some sense out there in the real world, as they can determine the otherwise undetermined idea of being. In that sense, Rosmini is a realist.

The key to Rosmini's understanding of how universal ideas are formed resides in this phrase: "the possibility of a thing extends to the unlimited repetition of that thing" ("la possibilità di una cosa s'estende alla ripetizione illimitata di quella cosa"). 
When reflecting on an individual perception - be it of a quality, an object, or a relation between things - we are capable of performing a mental act that multiplies the mental representation of that percept as many times as we want. We also realize that any such series of repetitions is in principle unlimited. It is this endless ideal series of identical copies of an individual perception that defines the universal and the class to which the perception belongs.

However, for all its psychological plausibility this theory of potentially endless repetition does not answer the fundamental question from where the idea of identity comes. What guarantee do we have that a process that is taken to be a repetition does, in fact, produce identical representational copies of the percept that is assumed to be multiplied in our mind? How do we know that they are identical if we do not already have access to the idea of identity? The mere fact that the idea of undetermined being, or possibility, distributes over all conceivable things clearly does not suffice. That idea would distribute over all thinkable things even if they were all unique, such that not two of them were qualitatively identical.

\section{Elementary concepts of the idea of being}

On closer scrutiny, one may question whether Rosmini is consistent in claiming that being is the one and only innate idea. The idea of being is said to have characteristics (caratteri) and natural qualities (naturali qualità). These are referred to as elementary concepts (concetti elementari), abstract concepts (concetti astratti), or simply “elements" of ideal being (Rosmini 1876, II: pp.158-9, sections 575-578): ${ }^{17}$

These elementary concepts, conditions for all human reasoning, are principally the following: $1^{\circ}$ unity; $2^{\circ}$ numbers; $3^{\circ}$ possibility; $4^{\circ}$ universality; $5^{o}$ necessity; $6^{\circ}$ immutability; $7^{\circ}$ absoluteness. [...]

All these concepts, contained in ideal being, are its characteristics, its natural qualities. Consequently, they are given to our mind together with being itself; we simply have to note them one by one, distinguish them within being, and assign each a name; we do this through various uses of the idea of being, and reflection. [...]

It should be noted that each of these abstract concepts is in itself an element of an idea rather than an idea; because on their own they provide no knowledge. For this reason, I call them elementary concepts of the ideal being; and generally speaking, the abstract ideas can be called elementary concepts of that idea from which they are abstracted.

The first five in the list resemble the corresponding Kantian categories: Einheit, Vielheit, Möglichkeit, Allheit, Notwendigkeit (Kant 1781, p.80). Yet, as quoted above, the Rosminian elementary concepts should not be understood as conditions of intellectual perception in the Kantian sense, but as conditions for the real existence of objects 
outside the mind (Rosmini 1875, I: pp.363-5, section 335). Rosmini maintains that objects cannot exist without having categorial properties. Nevertheless, consciously noticing and reflecting upon those properties is not a condition for an object to be perceived and judged to exist: "so, the understanding can conceive and perceive the object even without having to conceive and perceive its quantity, quality, and relationships." (Rosmini 1875, I: p.365, section 335).

What, then, does it mean that the Rosminian elementary concepts are "given to the mind together with being itself", although not as proper ideas in their own right? Let us charitably prescind from the blatant contradiction in terms, possibly a slip of the pen, when Rosmini occasionally refers to the elementary concepts as "abstract ideas", while at the same time maintaining that "each of these abstract concepts is in itself an element of an idea rather than an idea". Claiming that there is but one innate idea, that of being, one ought not, of course, simultaneously say that there are several innate abstract "ideas". As Rosmini emphatically insists that being is the one and only innate idea, for consistency to prevail the elementary concepts must be regarded as something else than innate ideas. How, then, is the inherence relation between being and its elementary concepts to be understood? On the one hand, the elementary concepts are not innate as separate ideas in the same sense as being, on the other they are given to the mind together with being. Writes Rosmini (1875, I: p.365, section 335): ${ }^{18}$

When the understanding has perceived an object proffered by the senses, it can also examine it and gradually discover its quantity, its qualities, and its relations. And this is how we perfect our knowledge. Knowledge exists by means of a judgment upon subsistence: it is perfected by means of more particular judgments about that which has already become the object of our spirit.

Thus, once the understanding (intendimento) has perceived an object by linking the idea of being to sensations, the spirit gradually discovers real properties in the object, some of which properties correspond to the elementary concepts that are inherent in the innate idea of being. When we reflect upon those properties, we clearly possess ideas corresponding to them. As for the psychology of the perception process, Rosmini seems to envisage that the real properties of an object elicit corresponding proper ideas in consequence of the fact that the combination of innate being with sensations makes one realize that there is an object. From a logical point of view, it seems clear that Rosmini considers material implication to hold between being (" $X$ exists") and the elementary concepts, e.g. that of numeri (e.g. " $X$ is quantifiable"). Indeed, in the above quotation (note 7) he explicitly writes that it is "implicitly contained" ("dove implicitamente si contiene...") in the existential statement that the thing sensed "must certainly be endowed with all the conditions of existence" ("...che 
dee essere fornita certo di tutte le condizioni dell'esistenza"; Rosmini 1875, I: p.364, section 335).

Could it be that the idea of qualitative identity reveals itself to the spirit in the same way as the elementary concepts and so need not be innate as a proper idea in its own right? It is noteworthy that Rosmini does not mention identity among the elementary concepts of being. Presumably, therefore, he regards identity as an idea originating more distally in the series of judgments originating with being and sensations.

More importantly, the idea of identity, in the presently relevant sense of a relation between two or more objects, presupposes the assumption of more than one object. Identity is not an internal property, without which an object could not exist. ${ }^{19}$ Hence, we must ask whether the idea of being, or the statement that something exists, implies that the world is a manifold.

The world as we know it consists of parts. Insofar as "being" means presence in the real world, it could perhaps be said to mean "existing as one of the world's parts" and hence to presuppose the manifold. However, although far-fetched, the theoretical existence of an indivisible, homogenous monolithic world does not seem overtly inconsistent. If, as seems likely, our usage permits us to express meaningfully the idea of such a world, being does not imply anything about the number of entities in the world.

Moreover, even if it were the case that the idea of being implied that the world is a manifold, and although necessarily there are relations between the entities of such a world, being does not imply that at least two of the entities are qualitatively identical. As pointed out above, the concept of a world containing but dissimilar parts does not seem to be inconsistent. Therefore, identity is not a characteristic or natural quality of being in analogy with the elementary concepts envisaged by Rosmini to be somehow contained in being.

\section{Concluding comments}

For the above reasons concerning the idea of identity, conjoined with the argument that there is no sensory system for detecting similarity in general without reference to any other specific sensory quality, I conclude that Rosmini is mistaken in claiming that being is the sole innate idea and that universals can be obtained by judgments ultimately based on being and sensations. If being is considered to be innate, then identity, and its logical negation difference, should also be so considered; not to mention further possible candidates. Either both being and identity are innate, or neither is.

Newborns are not generally believed to have ideas. Rosmini's claim that the idea Principia 20(3): 343-359 (2016). 
of being is innate must be understood to mean that infants have an inborn disposition for attributing existence to objects causing sensations, a disposition that becomes realized during infancy. Discussing Rosmini's views of psycholinguistic ontogenesis, Brugiatelli (2000b, pp.83-5) points out that the intuition of being is thought of as a primary, entirely unreflected, activity, requisite for and preceding that of attention. When, at some early point of development, attention is first awakened by sensations, this is coupled to the beginning of language acquisition, initially simply in the form of an interior "word" signifying that the individual feels the existence of something. This "solemn moment" marks the beginning of intelligent life and, according to Rosmini, reveals itself in the child's first smile. Subsequently, linked to the gradual expansion of linguistic competence, the ability to reflect on abstract ideas develops. Once one accepts the possible existence of innate ideas in the above sense, it seems natural to acknowledge that there may be more than one. For an illustrative simple example, consider the universals colour and sound. What property is common to different colour sensations, say of red and green, such that we naturally classify them as sensations of the same kind, that is to say of colour and not, for instance, of sound? If, as seems likely, we are born with a natural biological disposition for identifying perceptions of colours as colours and distinguishing them from sounds, we could as well say that the ideas of colour and sound are innate. If one considers that to be a misuse of the term "idea", it seems arbitrary and inconsistent to hold that the expression "innate idea of being" is not.

It may be speculated that besides purely philosophical reasons, theological motives may have encouraged Rosmini to consider being the one and only innate idea, thereby giving it an absolutely fundamental position in his system of thought. Although not identified with God, being is considered to be of divine origin and to appear in three forms: ideal, real, and moral. As indicated by Baggio (2016), the synthesis (Rosminian sintesismo) of these three forms into one concept of Being is reminiscent of the Christian doctrine of Trinity, a fact that may have limited meaning outside theology. However, without entering into a theological discussion of Rosminian thought, suffice it to note that regardless of whether, or of how many, ideas are innate, being is the most general universal. All mental or physical things, i.e. targets for consistent predication, "are".

\section{Acknowledgement}

Support from Fondazione Famiglia Rausing is gratefully acknowledged.

\section{References}

Baggio, A. 2016. Fondati in alto. Analogia e rivelazione in Rosmini. Canterano (Roma): Aracne editrice.

Principia 20(3): 343-359 (2016). 
Brugiatelli, V. 2000a. Il sentimento fondamentale nella filosofia di Rosmini. Rivista rosminiana di filosofia e di cultura 94(1): 39-73.

- 2000b. Il problema filosofico del linguaggio in Antonio Rosmini. Bologna: Edizioni Dehoniane Bologna.

Gentile, G. 1958. Rosmini e Gioberti. Saggio Storico sulla Filosofia Italiana del Risorgimento. In: Opere Complete di Giovanni Gentile, XXV (third edition). Firenze: Sansoni.

Hume, D. 1739. A Treatise of Human Nature. London: John Noon.

Kant, I. 1781. Critik der reinen Vernunft. Riga: Johann Friedrich Hartknoch

Locke, J. 1690/1825. An Essay Concerning Human Understanding. 25th ed. London: Thomas Tegg.

Rosmini-Serbati, A. 1875-76. Nuovo Saggio sull'Origine delle Idee. Vol. I-III. In: Opere Edite e Inedite dell'Abate Antonio Rosmini-Serbati, Roveretano (sixth edition). Intra: Paolo Bertolotti.

2001. A New Essay Concerning the Origin of Ideas. Vol. 1-3. Durham: Rosmini House.

\author{
INGE-BERT TÄLJEDAL \\ Umeå University \\ Umeå, Sweden \\ inge-bert@taljedal.se
}

\title{
Notes
}

1 “[...] sicchè, tolta via l'idea dell'essere, è reso impossibile il sapere umano e la mente stessa." The grave accent in "sicchè" is original. Here and in subsequent quotations, Rosmini deviates from modern standard Italian in using grave instead of acute accent in some words: sicchè, chechè, sè, nè, acciocchè, purchè, affinchè, chè.

${ }^{2}$ As regards Rosmini's use of the term "idea" and his overriding epistemological problem, he places himself right in the Lockean context (Rosmini 1875, I, p.12, section 41):

"Human beings have cognitions, think about various things, in brief, have ideas. I do not ask now what kind of thing the ideas are, but am content with the common notion that is missing in nobody; however, whatever they may be, I ask: from where do they come, or by which cause do they occur in the human spirit? [...]

When we form a judgment, we need to have in our mind already some universal ideas. [... ] However, if the human mind cannot perform the operation called judgment whithout first having in its possession some universal notion or idea, how then can it be that the human mind forms the universal ideas?"

"L'uomo possiede delle cognizioni, pensa a varie cose, ha in somma delle idee. Io non cerco ora che cosa sieno queste idee, contentandomi della notizia comune che a nessuno non ne manca ma, checchè si sieno, io domando: onde queste si producono o per quale cagione si trovano nello spirito umano? [...]

Quando noi formiamo un giudizio, abbiamo bisogno di possiedere già nella nostra mente delle nozioni universali. [...]

Ma se l'umana mente non può fare quell'operazione che si chiama giudizio, senz'essere prima

Principia 20(3): 343-359 (2016). 
in possesso di qualche nozione od idea universale; come poi avviene che l'umana mente si formi le idee universali?" This is how Locke opens Book 2 of his Essay (Locke 1690/1825, p.50):

"IDEA is the object of thinking. - Every man being conscious to himself that he thinks, and that which his mind is applied about whilst thinking, being the ideas that are there, it is past doubt, that men have in their mind several ideas, such as are those expressed by the words, whiteness, hardness, sweetness, thinking, motion, man, elephant, army, drunkenness, and others: it is in the first place then to be enquired, how he comes by them?"

Whereas simple ideas are seemingly direct sensory effects on the mind in Locke (1690/1825, p.51), and copies of impressions (to which sensations belong) in Hume (1739, p.4), Rosminian ideas are either innate (being) or formed from sensations in combination with the innate idea of being. Although Reid realized that the derivation of ideas from sensations has the character of judgment, according to Rosmini (1875, I: pp.77-103, sections 109-133) he did not realize the need for an innate first idea in order to make possible the judgments.

${ }^{3}$ Regardless of the longstanding criticisms of innatism (e.g. Locke 1690/1825, pp.8-50), I think it is fair to analyze the internal consistency of Rosmini's epistemology, accepting for the sake of argument that an innate idea of being is both logically and empirically possible. Rosmini shares with Locke the conviction that the vast majority of principles and ideas are acquired; it is only the intuition of undetermined being that is supposed to be innate. As pointed out in my Concluding comments, it lies close at hand to interpret Rosmini as having a dispositional view of innateness. Although I do not want to advocate a personal stance on whether the intuition of being is, as a matter of fact, innate, I do not find a dispositional view of the matter any more absurd than the common view that many gradually developing biological abilities are innate.

4 The first volume of Nuovo Saggio appeared anonymously in 1830 with the publisher Salviucci, Rome. I do not believe that Rosmini ever abandoned the basic tenets of epistemology expressed in Nuovo Saggio, but he wrote copiously on both philosophy and theology and I do not claim to possess thorough knowledge of his complete works.

5 "Conchiudiamo: la mente umana non ha nessuna forma determinata innata: e le diciassette forme del Kant non hanno alcun vero fondamento, e sono interamente superflue a spiegar l'origine delle idee.

All'incontro la mente umana ha una sola forma indeterminata, e questa è l'idea dell'ente in universale.

L'idea dell'ente in universale è pura forma e non ha seco congiunto nessun elemento materiale: non è soggettiva, anzi per sè oggetto: essa è così semplice e poca cosa, che non si può semplificare più oltre, nè immaginare nulla di meno che possa essere atto a informare le nostre cognizioni: nello stesso tempo è di una fecondità infinita.

E veramente egli è impossibile immaginare un atto qualunque della mente, che di questa forma non abbisogni, e per essa non si naturi e si informi; sicchè, tolta via l'idea dell'essere, è reso impossibile il sapere umano e la mente stessa."

6 "Per illustrare la cosa con un esempio, poniamo che colpisca i miei sensi un agente sensibile qualunque, un albero, un sasso, una bestia ecc. Io avrò primieramente tutte le sensazioni che quell'agente sensibile produce ne' miei sensi, la sensazione del colore, della grandezza, della figura, del moto ecc. Ora fino che io ho tutte queste sensazioni passivamente, e senza alcuna operazione del mio intendimento, quali modificazioni della mia sensitività, io non ho ancora 
concepito alcun ente in un modo intellettuale. Acciocchè io lo concepisca intellettualmente, il mio spirito deve pronunciare un giudizio, cioè dire a se stesso "esiste qualche cosa dotata delle qualità sensibili, tali e tali ecc." (cioè delle qualità percepite da' miei sensi). Ora pronunciando un tal giudizio, io non fo che attribuir l'esistenza a un reale, di cui io ho percepite co' sensi le sole sensibili qualità, e così percepisco l'ente stesso intellettualmente. L'idea universale di cui io fo uso in questo giudizio, è l'idea di esistenza, e se io non l'avessi precedentemente, sarebbe impossibile che io la applicassi alle mie sensazioni [...]"

7 "Il Kant suppone gratuitamente che noi, quantunque volte percepiamo una cosa esterna coll'intendimento, siamo obbligati di percepire intellettualmente altresi la sua quantita [sic: missing accent], la sua qualità, e la sua relazione. In questo egli mostra di non avere abbastanza approfondito la natura di quell'atto intellettuale, col quale noi percepiamo le cose.

Infatti, acciocchè io possa col mio intendimento percepire una realità, è bensì necessario ch'io la giudichi esistente; ma su tutto il resto, non è necessario ch'io pronunzi giudizio: non è necessario ch'io attribuisca alla medesima espressamente una quantità, qualità e relazione. Sopra tutte queste cose io posso sospendere il mio giudizio, e tuttavia percepire intellettualmente la cosa: purchè io dica a me stesso: "esiste".

Questo giudizio che io fo nel primo atto della percezione intellettuale, si potrebbe esprimere così: "Esiste qualche cosa che modifica i miei sensi", dove implicitamente si contiene che dee essere fornita certo di tutte le condizioni dell'esistenza. [...]

L'errore kantiano dunque qui consiste nell'aver egli supposto che le quattro categorie, cioè la quantità, la qualità, la relazione e la modalità, sieno condizioni della percezione intellettuale, o, com'egli dice, dell'esperienza: mentre non sono che condizioni dell'esistenza delle cose esterne.

Certo, nessuna cosa corporea può esistere senza una quantità, senza qualità e senza relazioni: ma tutte queste cose, che pure in lei o a lei sono, non è necessario che sieno da me, insieme con essa, intellettualmente percepite, affinchè io possa dire d'aver percepita o concepita la cosa. Anzi in ogni cosa ci rimangano sempre occulte molte proprietà, che si scoprono poscia col tratto del tempo, e col lungo esame; eppure la cosa si potè benissimo aver percepita, senza aver pensato a quelle proprietà o qualità."

8 "Laonde, ridotto in tal modo quanto ci può esser d'innato nella mente dell'uomo al menemo possibile, non mi resta ora che a mostrare come questo poco sia tuttavia sufficiente a spiegare completamente l'origine di tutte le nostre idee..."

9 "E veramente la difficoltà da me proposta consiste nello spiegare il modo, onde noi cominciamo a giudicare. Che se una sola idea è innata, n'abbiamo già abbastanza: chè col far uso di quest'idea noi possiamo avere a nostro agio una serie di giudizi; e questi giudizi darci delle altre idee; e quindi far con esse altri ed altri giudizi, e cavarne altre ed altre idee. Convien dunque esaminar bene la genealogia delle idee: questo esame ci conduce a trovar di tutte un solo stipite, una idea prima, l'essenza delle idee, colla qual sola noi veniamo ad aver perfetta la facoltà di giudicare."

10 "Abbiamo veduto, che nell'uomo è $1^{\circ}$ la sensazione (1), $2^{\circ}$ l'idea dell'essere, $3^{\circ}$ ed una forza unica (il soggetto senziente ed intelligente) che unisce il sentito e l'idea dell'essere, e forma la percezione intellettiva delle cose.

Sulle percezioni intellettive lo spirito riflette, e riflettendo vi esercita diverse operazioni, colle quali ne cava le idee, e mediante queste, unisce e scompone idee e percezioni, forma continuamente giudizi e raziocini.

Principia 20(3): 343-359 (2016). 
Tutte le cognizioni umane da questi pochi fonti scaturiscono.

Ora la semplice sensazione non si può ancora chiamare cognizione: essa non è che la materia della cognizione."

${ }^{11}$ Footnote belonging to the original: "(1) In sensations I also include images, which are reactivated previous sensations, and the fundamental feeling which is a kind of universal, permanent sensation of ourselves." "(1) Alle sensazioni intendo che sieno ridotte anche le immagini, che sono rinnovamenti di sensazioni sofferte, e il sentimento fondamentale che è come una sensazione universale e permanente di noi stessi."

12 "[S]i può classificar nulla, se non si suppone di possedere precedentemente l'idea generale che costituisce la classe: cioè non si può paragonare, e conoscere ciò che è simile e ciò che è dissimile in due individui, se non si possiede innanzi quell'idea astratta nella quale i due individui convengono; chè altrimenti si percepirebbero i due individui simili, per esempio, i due panni rossi, ma non si penserebbe punto, non si rifletterebbe alla loro somiglianza; le due sensazioni rosse, percepite co' nostri sensori, resterebbero così divise, come divise sono veramente fino che restano sensazioni, divise almeno di tempo o di luogo, per la quale divisione l'una ha un'esistenza distinta incognita all'altra, ed all'altra incomunicabile [... ] La riflessione lockiana dunque, la riflessione sulle sensazioni nostre a intendimento di cavar da esse delle idee senza possederne alcuna precedentemente, è impossibile; sono anzi le idee quelle che dirigono lo spirito nelle sue riflessioni, e che danno a questo la possibilità di unire e scomporre le sensazioni, e di trasportare liberamente dall'una all'altra la sua attenzione." 13 "Similarity" is here taken to mean proximity in cases where the quality under consideration is graded. For example, objects can be classified as "white objects", although not two of them are literally identical in colour. In such cases, "identity" is the basic notion, "similar" meaning "nearly identical", or identical with respect to the somewhat vague quality "whiteness". Henceforth, what is said about "identity" applies accordingly to "similarity". For simplicity, unspecified "identity" means qualitative identity. Identity is logically prior to the formation of other universals, regardless of whether the universals are derived by abstraction from known phenomena or, as may happen in the progress of science, proposed on theoretical grounds from the observation of newly discovered individuals.

${ }^{14}$ Although it may be that nothing can exist unless it is numerically identical to itself, and although numerical identity entails qualitative identity, one can disregard such metaphysics in the present context. What matters here is qualitative identity between numerically distinct entities.

15 "E di vero, noi abbiamo dimostrato, che nell'idea pura non si pensa che la possibilità, senza che nulla si comprenda della sussistenza della cosa [...]: abbiamo dimostrato ancora, che la possibilità di una cosa s'estende alla ripetizione illimitata di quella cosa, e non si può pensar che non sia; il che è quanto dire, che nella possibilità si contengono i caratteri d'universalità e di necessità $[\ldots]$.

E veramente è sempre l'idea dell'essere quella che, vestita di qualità determinanti cavate dall'esperienza, mi sommistra una quantità di idee ossia concetti, più o meno determinati, ma che non rappresentano che entità meramente possibili, e non ancora sussistenti."

${ }^{16}$ In Rosmini "subsistence" ("sussistenza") means real existence outside the mind.

17 "Questi concetti elementari, condizioni di tutti gli umani ragionamenti, sono principalmente i seguenti: $1^{\circ}$ quello di unità, $2^{\circ}$ de' numeri, $3^{\circ}$ di possibilità, $4^{\circ}$ d'universalità, $5^{\circ}$ di necessità, $6^{\circ}$ d'immutabilità, $7^{\circ}$ e di assolutezza. [... ]

Principia 20(3): 343-359 (2016). 
Tutti questi concetti, racchiusi nell'essere ideale, sono suoi caratteri, sue naturali qualità. Essi dunque sono dati alla mente nostra coll'essere stesso; nè a noi resta altra fatica, se non quella di notarli ad uno ad uno, di distinguerli in esso, e di segnare ciascuno con un nome; il che si fa mediante il vario uso dell'idea dell'essere, e la riflessione. [... ]

Noterò solo, che questi concetti astratti, ciascuno preso da sè è più tosto un elemento d'idea, che un'idea; chè essi soli niente fanno conoscere. Per questo anco io li chiamo concetti elementari dell'essere ideale; e in generale le idee astratte si possono dire concetti elementari di quella idea onde vengono astratte."

18 "Quando poi l'intendimento ha percepito una cosa offerta dai sensi, egli può anche esaminarla, e trovare a mano a mano la sua quantità, le sue qualità e le sue relazioni. Ed è così che perfeziona la nostra cognizione. Ella esiste mediante il giudizio sulla sussistenza: si perfeziona mediante altri giudizi più particolari, portati sopra ciò che è già divenuto oggetto del nostro spirito."

${ }^{19}$ Auto-identity or quantitative identity is not relevant here. However, to the extent that autoidentity is intelligible, it probably would not be so unless we knew what it means for an object to be identical to another. It should be noted that when Locke (1690/1825, pp.36-7) argues against identity being an innate idea, he is referring to quantitative, not qualitative, identity.

Principia 20(3): 343-359 (2016). 